\title{
Projekt Matoševa spomenika u Zagrebu godine 1938. s pregledom vrijedne likovne „matošiane"
}

ABSTRACT. Čorkalo Jemrić Katica, Projekt Matoševa spomenika u Zagrebu godine 1938. s pregledom vrijedne likovne ,matošiane” (The Project of Matoš Monument in Zagreb in 1938 and an Overview of the Valuable Visual Art Works of „Matošiana”). „Poznańskie Studia Slawistyczne" 7. Poznań 2014. Publishing House Science and Innovate, pp. 63-78. ISBN 978-83-63795-79-5. ISSN 2084-3011.

The paper describes the first organized attempt to erect a monument to A.G. Matoš in Zagreb (1938), an erected monument - Matoš on the bench - made by I. Kozarić (1978), as well as other visual art works inspired by Matoš - portraits, busts, and caricatures. At the end a description of the memorial house of Matoš and other memorials in his born-town Tovarnik is given, with emphasizing of the future activities in the memorial house. Inspired by the important book To the memory of A.G. Matoš, this paper gives an overview of the memorial heritage dedicated to the great poet.

Keywords: the unrealized monument to Antun Gustav Matoš in Zagreb; the monument of Ivan Kožarić; busts; portraits; caricatures; Antun Gustav Matoš in Tovarnik

\section{Uvod}

Velikan hrvatske moderne, jedini koji je u tisućljetnoj književnoj baštini okupio sljedbenike svoje poetike (matoševce), Antun Gustav Matoš primjer je nesrećom obilježena književnika kakvi su u hrvatskoj prošlosti češće pravilo nego iznimka. Zla kob, oskudica, nesporazumi i prijepori s neistomišljenicima pratili su ga cijelog života. Aludirajući u nedovršenoj Autobiografiji na fatumsku znakovitost datuma rođenja - petak 13. lip- 
nja 1873., uopćavajući, zaključuje: „Petak i trinaesti ostadoše moji važni datumi i osim rođenja" (Matoš 1995: 171). Ipak nije mogao znati da će se aluzivni biografski nagovještaj tvrdokorno ostvarivati i nakon njegove prerane smrti u noći ${ }^{1}$ 17. ožujka 1914., jer zagriženi protagonisti sukoba nisu mogli oprostiti ni mrtvom Matošu, o čemu, varirajući temu, svjedoči Krleža:

Na Mirogoju, nad otvorenim grobom A.G.M.-a govorio je Julije [Benešić! - K.Č.J.], u crnom salonroku (...), a one karmine kod Milčeka M.-a [Milana Marjanovića! K.Č.J.] pretvorile su se u histerično ogovaranje mrtvog Matoša (Krleža 1977: 183).

Ostavio sam našu literarnu kremu tamo na karminama i preko Orlovca popeo se na Cmrok (...). Plač na proljetnoj kiši za jednim Perom koje se slomilo, a do kojega nam nije bilo stalo dok je pisalo živo. (...) Značenje vrijednosti njegovih tekstova objavljuje se tek mnogo kasnije, iz retrospektive, tek negdje oko 1921 - 28. Karmine kod M. M.-a [Milana Marjanovića! - K.Č.J.] bile su moj prvi šok (Krleža 1977: 22)2.

Znalcima Matoševa opusa to su manje-više poznate činjenice, no manje je poznato da se ideološki diktirana politika sudbonosno uplela i u prvo ozbiljno nastojanje oko podignuća Matoševa spomenika u Zagrebu, na čemu su 1938. nastojali njegovi književni kolege, prijatelji i poštovatelji. Dakle, ne može se reći kako nije bilo volje da neumrli Matoš dobije spomenik u prijestolnom gradu koji je smatrao svojim i svim mu srcem pripadao, što u oproštajnom govoru „nad otvorenim grobom” na Mirogoju ističe i Julije Benešić, povezujući ga s najzagrebačkijim hrvatskim piscem Šenoom: „Eno Ti pruža ruku pisac Zagrebulja pozdravljajući do smrti Zagrebu vjernoga Matoša!” (Matoš 1939b: 152). Isticali su ljubav prema Zagrebu svi koji su se Matošem i njegovim djelom bavili, pa je jedan od dvaju urednika prvog izdanja njegove književne ostavštine, već spomenuti

1 Sa smrtne postelje u bolnici Sestara milosrdnica u Vinogradskoj ulici slao je Matoš uredniku „Savremenika” Branimiru Livadiću svoje pjesme, među njima i posthumno objavljeni sonet Notturno, ,jednu od najboljih svojih pjesama” (Krleža 1988: 199) - oporučnu pjesmu (Frangeš 1982: 732).

2, ,...) najdramatičnija primopredaja u novijoj hrvatskoj književnosti” (Frangeš 1982: 690) dogodila se 1914. godine: umire Matoš, na zalasku moderne izlazi antologija Hrvatska mlada lirika kao suma njegova utjecaja na poetiku mladih, dok istodobno Krleža u Marjanovićevim „Književnim novostima” na velika vrata ulazi u hrvatsku književnost dramom Legenda. 
J. Benešić, osmu knjigu niza Matoševih Djela ${ }^{3}$ naslovio Oko Zagreba i po Hrvatskoj ${ }^{4}$.

Ljubav prema Zagrebu upisao je Matoš u pjesme i brojne prozne zapise, izričito se nazivajući Zagrepčaninom i neuvijeno iznoseći zanosne osjećaje prema gradu uz koji ga vežu dječačke i đačke uspomene, zadivljenost kulturnom poviješću i krajolicima, a nadasve do bola žarko, romantično rodoljublje:

Zagreb je barem za nas Zagrepčane najljepši grad na svijetu.

Na čitavom svijetu nema možda šetališta, hrastovog šetališta kao Tuškanac. Drveće u renomiranoj Bulonjskoj šumi kraj Pariza prava je karikatura našeg Tuškanca, o maksimirskim divnim dubovima, punim sjene, okrepe i mira, da i ne besjedim.

Zagreb, bio kakav mu drago, središte je Hrvatske i hrvatstva, pa nije dobar Hrvat koji nije dobar Zagrepčanin (Matoš 1939a: 56, 82, 111).

Kad ne mogoh boraviti u tome gradu - bez kojega u ostalom ne mogoh biti (...) čeznuo sam za Zagrebom kao Hrvat za Hrvatskom, kao vojnik za civilom, kao uznik za slobodom.

Jer pored tih tolikih i takvih Zagreba ima još jedan Zagreb, hrvatski kao grička tradicija, zanosan kao tornjevi nove katedrale, domaći i narodan kao krasni zagrebački pejzaž, zdrav kao divna okolica zagrebačka. To je Zagreb što radi, što se muči, što trpi, što ne očajava (...), prava Hrvatska u Zagrebu (Matoš 1939b: 38, 43).

A što se pak tiče naše teme o prvom nastojanju da Matoš dva i pol desetljeća poslije smrti dobije spomenik u Zagrebu, evo što kaže on sâm: „U Zagrebu imaju veće spomenike tek Jelačić, Preradović i Kačić” (Matoš

${ }^{3}$ Djela A.G. Matoša u izdanju zagrebačke Binoze prvi su pokušaj sinteze opsežne Matoševe ostavštine u sedamnaest knjiga, koju je sabrao najmlađi Matošev brat Milan Matoš. Pokrenuta 1935., Djela su izlazila do 1940.: svesci 1. i 2. (1935.), svezak 3. (1936.), svezak 4. (1937.), svesci 5., 6. i 7. (1938.), svesci 8. i 9. (1939.), svesci 10. do 17. (1940.). Prvih je sedam knjiga priredio Antun Barac, a preostalih deset Julije Benešić, objavivši u samo dvije godine, 1939. i 1940, deset knjiga, nažalost, bez godine izlaska. Naknadno je godine izdanja utvrdio neumorni bibliograf Dragutin Tadijanović. Binozino izdanje najambiciozniji je nakladnički pothvat sve do kritičkog izdanja Sabranih djela A.G. Matoša u dvadeset svezaka (JAZU-Liber-Mladost, Zagreb 1973.), za koje je najviše zaslužan već spomenuti poštovalac Matoševa djela - Tadijanović.

${ }^{4}$ U knjigu Oko Zagreba i po Hrvatskoj uvršteni su i ovi rječito zagrebocentrični prilozi: Zagreb po danu, Kod kuće, Božićnica Zagreba, Dva grada (čuvena Matoševa usporedba Zagreba i Beograda!), Zagrebačko pismo, Zagrebački Beedeker, Zagrebačka kronika. 
1939a: 55). Ostavio je prešućenom implicitnu misao da ni jedan od njih nije „Zagrepčanec”.

\section{Prvi, nerealizirani projekt Matoševa spomenika u Zagrebu}

Upravo zato na značenju dobiva projekt Odbora za podignuće Matoševa spomenika sadržan u knjizi Uspomeni A.G. Matoša (Ivakić 1938), koja govori o namjerama Odbora ${ }^{5}$ da knjigom tekstova posvećenih Matošu prikupi novac za njegov spomenik u Zagrebu. U plavo platno uvezana i pozlatom naslova okićena, spomen-knjiga složena je od žanrovski različitih tekstova, s nakanom da probranim sadržajem privuče pretplatnike i podupiratelje Matoševa monumenta. Tekstovima prethodi na kunstdruku donesen Fragment spomenika A.G. Matošu kipara Rudolfa (Rude) Ivankovića ${ }^{6}$ i verzalom otisnuta namjera: „OVO SE DJELO / UZ / DOBROHOTNU SURADNJU / NAŠIH KNJIŽEVNIKA / PRODAJE / U KORIST PODIGNUĆA / SPOMENIKA / A.G. MATOŠU / U ZAGREBU" (Ivakić 1938: [3]).

Ivakićev uvodnik obrazlaže zašto Matoš treba dobiti spomenik u Zagrebu, a nepotpisana bilješka na kraju knjige govori o realizaciji projekta (Ivakić 1938: 5-8, 157). Ideju o spomeniku propagirao je Odbor u domaćemu tisku i činilo se da mogu računati na uspjeh, pogotovo kad su dobili potporu najutjecajnijega hrvatskoga političara dr. Vladka Mačeka, pa tadašnje novine već najavljuju da „Matošev spomenik na pragu Zagreba čeka da uđe u Zagreb” („Večer” 1938: 3). No Ivankovićev spomenik nije ušao u grad, ni tada ni poslije, ali je u Zagreb ušao rat i odredio sudbinu istaknutih članova Odbora i autora - ljevičara (Branimir Ivakić, Branimir Gršković, Antun Barac), no bilo je među njima i pravaša (Milan Ogrizović) te ideološki neopredijeljenih (Ivan Esih) i Matošu bliskih boemskih natura (Vjekoslav Majer i Ljubo Wiesner).

5 Odbor se konstituirao i vlastima prijavio u sastavu: predsjednik dr. B. Ivakić, tajnik B. Gršković, blagajnik Alfred Bauman, odbornici dr. I. Esih, Josip Pavičić i Radovan Žilić.

${ }^{6}$ Suradnik Augustinčićeve majstorske radionice, Ivanković je dotad već stekao reputaciju kipara koji oblikuje javne spomenike (npr. reljef Augusta Šenoe u Zagrebu i Antuna Mihanovića u Klanjcu). 
Rudolf Ivanković, Spomenik Matošu, objavljen u knjizi Uspomeni A.G. Matoša, ur. B. Ivakić,

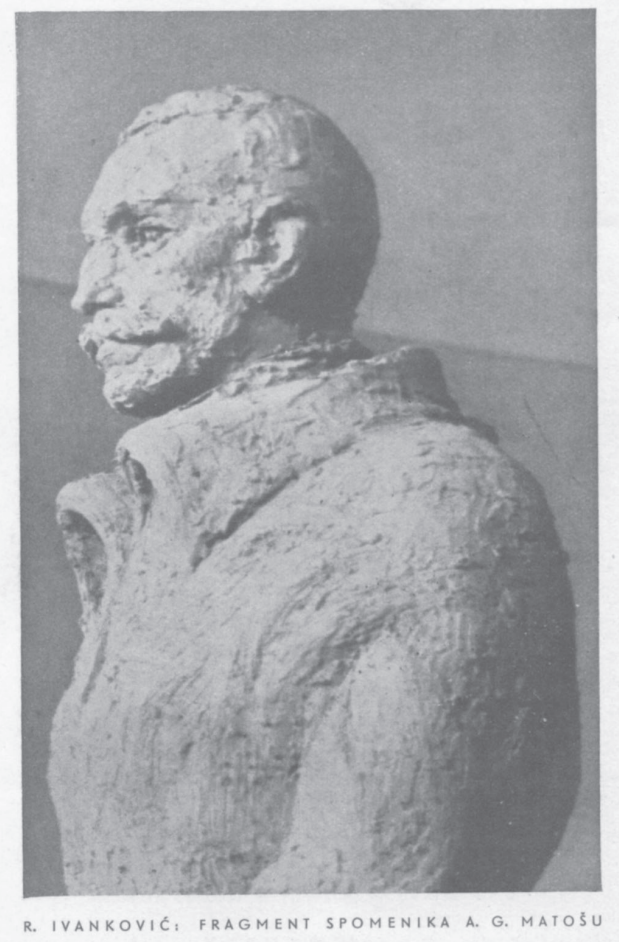
Zagreb 1938.

Spomen-knjigu Uspomeni A.G. Matoš $a^{7}$ otvara studija M. Ogrizovića koja već naslovom Artista (Ivakić 1938: 9-47) definira narav Matoševe umjetničke biti, umijeće da riječima postigne začudan učinak. Ugledni književni povjesničar i urednik sedam knjiga Matoševih Djela (1934.-1938.),

7 Sadržaj knjige čine izabrani, već prije objavljeni i kronološki poredani tekstovi: M. Ogrizovića Artista („Hrvatska smotra” 1907), A. Barca Matoševa lirika („Savremenik” 1919), V. Lunačeka Matoš (Predgovor Umornim pričama 1917), Ksavera Š. Gjalskog Nekoje uspomene na Matoša (,Savremenik” 1929), Božidara S. Nikolajevića Matoševi boravci u Beogradu („Novosti” 1928), dio nedovršene Wiesnerove monografije Matoš u Parizu i Esihov esej Živi Matoš. Uz navedene je članke kronološkim redom nastanka složeno i šest Matošu posvećenih pjesama: Lj. Wiesnera Nad versima A.G. Matoša, Vjekoslava Majera Plinska laterna na Griču i Na grobu Matoša, R. Žilića, Modri grad i Posljednji petak Matoša te pjesma Dobriše Cesarića Trubač sa Seine (Matoš u Parizu). 
Antun Barac ${ }^{8}$, za ovu je prigodu priložio studiju Matoševa lirika (1938: 49-68), jer su upravo pjesme „kadre da Matošu osiguraju trajno ime u historiji naše literature" (Ivakić 1938: 62). Za razliku od Barca, Vladimir Lunaček nije razumio Matoša pjesnika. Proglasivši pukim formalizmom njegovu težnju za savršenstvom forme, izrekao je blasfemičnu misao da bi bolje bilo da svojih pjesama nikad ni napisao nije (Ivakić 1938: 81). Sklon i inače ishitrenim prosudbama, sâm bi pak Lunaček bolje učinio da je svoje mišljenje o Matoševim pjesmama zadržao za sebe 9 . Pišući s vremenskim odmakom Nekoje uspomene na Matoša, prisjeća se Gjalski ${ }^{10}$ rijetkih susreta s ,velikim mučenikom” i zaključuje: „Bio mi je drag kano tolikogodišnji patnik i kano tako stalan i vjeran Hrvat” (Ivakić 1938: 90).

Među uknjiženim člancima dva su informativna priloga o dvama razdobljima Matoševa života, beogradskom i pariškom: Nikolajevićevi ${ }^{11} \mathrm{Ma}$ toševi boravci u Beogradu i ulomak nedovršene Wiesnerove ${ }^{12}$ monografije Matoš u Parizu, koju je kao najodaniji učenik Rabija pisao cijelog života, ali mu je većina rukopisa propala u Drugome svjetskom ratu ${ }^{13}$. Posljednji tekst u knjizi Esihov je esej znakovita naslova Živi Matoš, jer je kao malo koji od književnih velikana utjecao na svoj i sljedeće književne naraštaje, bitno obilježivši hrvatsku književnost u cjelini, a legenda je o njemu rasla, umnažala istraživače njegova djela i pretakala se u pjesme, koje su u međuvremenu sa šest naslova četvorice pjesnika zastupljenih u knjizi Uspomeni A.G. Matoša, narasle u impozantnu zbirku od trideset i devet pjesama dva-

${ }^{8} \mathrm{Kad}$ je 1938. pokrenut projekt Matoševa spomenika, A. Barac upravo je izabran za redovnoga profesora Filozofskog fakulteta u Zagrebu. Iza sebe je imao pet objavljenih znanstvenih knjiga, a od toga monografije Vladimir Nazor (1918) i August Šenoa (1926).

${ }^{9}$ Lunačeka se tada nije moglo zaobići, ni kao autora predgovora Matoš u izdanju Umorne priče: vidici i putovi (Zagreb, 1917), a ni kao arbitra moderne, zaslužna za portrete Dragutina Domjanića, Vladimira Vidrića i osobito Matoša.

${ }^{10}$ Prema svjedočenju brata Milana, Matoš je izdahnuo s rukom na Gjalskijevoj knjizi Na rođenoj grudi, koju mu je dodao da napiše to što je htio reći, no iznemogli Matoš više nije mogao ni govoriti ni pisati (Žeželj 1970: 462).

11 Dr. B.S. Nikolajević upoznao je Matoša u Beogradu 1894. godine, prijateljevao s njim i razmjenjivao misli u kultnoj kavani „,Dardaneli”.

12 Pjesnik, kritičar i publicist Lj. Wiesner, urednik čuvene antologije Hrvatska mlada lirika, u predgovoru iznosi program Matoševih učenika okupljenih poslije oko časopisa „Grič”, pa ga Krleža naziva „izvršiteljem pjesničke oporuke Matoševe” (Frangeš 1982: 719).

13 Neumornom je Tadijanoviću uspjelo skupiti raspršene fragmente Wiesnerove Studije o A.G. Matošu i objaviti ih u 22 naslova (Frangeš, Tadijanović 1994). 
deset i šestorice autora (Frangeš, Tadijanović 1994), jer očito niti jedan naš književnik nije nadolazećim naraštajima bio u tolikoj mjeri inspirativan i poetski poticajan kao Matoš. A i pjesme su spomenici Matošu - u riječi.

Iz današnje perspektive gledajući, knjiga Uspomeni A.G. Matoša otvara pogled na tragične ratne sudbine najvažnijih članova Odbora, dvaju Branimira: predsjednika Ivakića ${ }^{14}$ i tajnika Grškovića ${ }^{15}$. Ivakića su ustaške vlasti uhitile 1943. i s još petnaestoricom talaca osudile na smrt vješanjem zbog ilegalnog djelovanja ${ }^{16}$, a Gršković je više puta zatvaran 1943. i 1944. te također u skupini talaca ubijen pri kraju rata 1945. Okupaciju je preživio Barac, zatočenik logora Jasenovac i Stara Gradiška (studeni 1941. - svibanj 1942). Naravno da zagovornik samostalne hrvatske države i starčevićanac Matoš, po naravi stvari, nije mogao biti spomenički uzveličan u dvjema Jugoslavijama, ni versajskoj ni avnojskoj. Čekalo se na to punih četrdeset godina.

\section{Napokon spomenik A.G. Matošu u Zagrebu}

Napokon su se sedamdesetih godina 20. stoljeća stekli uvjeti i za taj čin, i to zaslugom kipara Ivana Kožarića - „baštinika stečenih povijesnih avangardi" (Denegri 2006: [nepag.]) i predstavnika naraštaja koji je zatečeno stanje u umjetnosti mijenjao u korist ,nove umjetnosti”, odnosno „,nove umjetničke prakse". Njegov spomenik Pjesnik Zagrebu iz $1973{ }^{17}$. osvojio je izvedbenu nagradu 13. zagrebačkog salona za skulpture 1978. te je pod novim imenom Matoš na klupi potkraj te iste godine smješten na povijesni prostor Strossmayerova šetališta - ,s leđa zasjenjen zdanjima Gornjega gra-

${ }^{14}$ Branimir Ivakić, glazbeni i književni kritičar, sin je slavnijega Vinkovčanina Joze Ivakića, književnika, kazališnog i filmskog redatelja. Za Nezavisne Države Hrvatske vježbenik je u Odjelu za seljačko gospodarstvo 1940.-1941. i novinar u Hrvatskom dojavnom uredu „Croatia”, a istodobno surađuje u zagrebačkim ilegalnim listovima „Vijesti” (1942) i „Narodna borba” (1943) (Vončina 2005: 62-63).

15 B. Gršković, kazališni kritičar i novinar, predratni član KPJ, otpočetka Drugoga svjetskog rata uključio se u ilegalni rad (Pintar 2002: 244).

${ }^{16}$ (HDU-Hrvatski državni ured) Vješanje redarstveno utvrđenih komunista i djelatnih partizana („Hrvatski narod”, 5/1943, 21.12., str. 10).

${ }^{17} \mathrm{U}$ mnogim izvorima, pa i najnovijima u vezi s pariškim Matošem, pogrešno se navodi 1972. godina. 

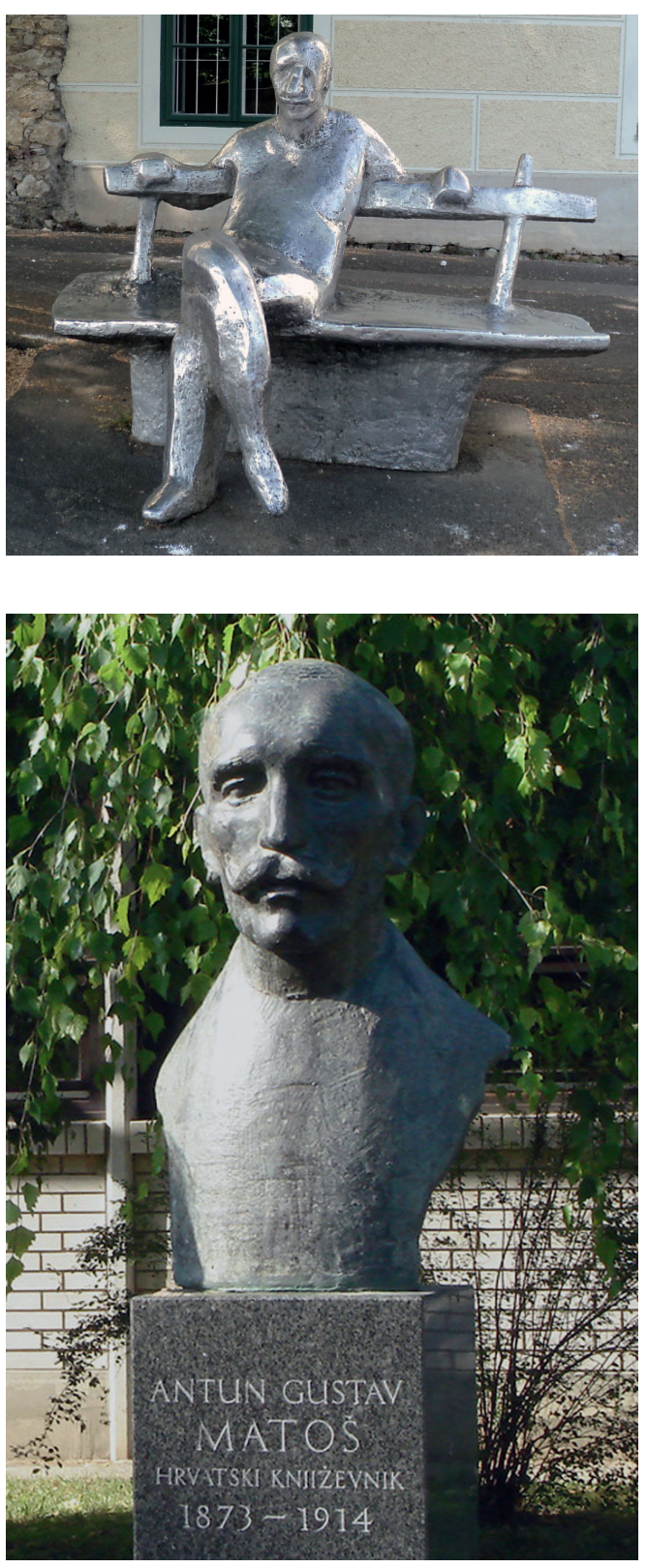

Ivan Kožarić, Matoš na klupi,

Strossmayerovo šetalište u Zagrebu, aluminij, 1972.
Mihael Kajfeš, Poprsje

A.G. Matoša pred školom u Tovarniku, bronca, 1974. 
da i s vidicima juga što pucaju na prekosavlje" (Tenžera 1978: 8). Dogodilo se to o 105-oj obljetnici pjesnikova rođenja.

Ako je spomenik simbol čovjeka i preobrazba umjetnikove misli u materiju kipa, onda Kožarićeva skulptura ispunjava sve preduvjete za to. Izrađen $\mathrm{u}$ aluminiju, bio je to prvi spomenik s otklonom od tradicijskih uzusa, načinjen u dosluhu s Matoševim životom i s ciljem da približi pjesnika kako bi postao dionikom gradske svakodnevice. Spomenik nema uobičajeni postament, nego Matoš ležerno sjedi na klupi prekriženih nogu i s rukama raširenima na naslonu klupe te tako opušten, pogledom upravljenim prema Zagrebu, promatra kako oko njega užurbano teče život današnjeg čovjeka. Kožarićevu skulpturu ne gledamo kako smo naviknuli gledati kiparske monumente, iz žablje perspektive, nego je Matoš tu, među nama, u srcu starog Griča-grada, koji je silno volio i uzastopno mu posvećivao zapise sjajnih lirskih nadahnuća. Asimetrično smješten na lijevu stranu klupe, ostavlja Matoš na svojoj desnoj strani mjesto našima i strancima da sjednu i uživaju u panorami Zagreba i njegovu društvu, dok u neposrednom zaleđu odjekuju glasovi mladeži gornjogradske gimnazije. Nakon prvih nedoumica zbog nekonvencionalnosti spomenika, Kožarićev Matoš na klupi pozitivno je odjeknuo u javnosti, a njegova se replika, postavljena 1992. u Sisku na šetnici uz Kupu, također izvrsno uklopila. Dakako, ambijentalna vizura Matoša promatrača ovdje je bitno drukčija, no i tu je uključen u život prolaznika.

A u najnovije vrijeme, 8. veljače 2014., dogodio se i treći Kožarićev Matoš na klupi, zaputivši se sa ,zagrebačkoga Gornjega grada, preko sisačke šetnice, sve do okolice Pariza" (Lončar 2014: 2) u park Roseraie u gradiću Issy les Moulineaux i to na poticaj Udruge AMCA naših bivših pariških studenata $^{18}$. Skulptura je i tu postavljena na mjesto koje odgovara umjetnikovoj zamisli interakcije i komuniciranja spomeničkog Matoša s ambijentom i njegovim posjetiteljima. Tako se najveći naš ,parizlija” i frankofil opet našao u prostoru svojih književnih hodočašća i nadahnuća, u godini koju je, njemu u čast, i Opća skupština UNESCO-a stavila u program poticanja suradnje među različitim kulturama.

18 Svečanošću je obilježena 100. godišnjica Matoševe smrti u prisutnosti ministrice kulture Republike Hrvatske A. Zlatar Violić, hrvatskoga veleposlanika u Francuskoj Ive Goldsteina, gradonačelnika spomenuta gradića Andréa Lévya te predsjednika Udruge inicijatora Damira Perinića. 


\section{Ostala likovna „matošiana”}

Na dan Matoševe smrti 17. ožujka 1914. kipar Robert Jean Ivanović snimio je u bolnici Sestara milosrdnica njegovu posmrtnu masku. No prvi odljev te maske izložen je tek na izložbi A.G. Matoš Akademijina Instituta za književnost 1954. godine, koju je priredio znalac Matoševa života i rada, i s njim u vezi već spominjani Tadijanović. Također su tu izložene skice za spomenik Matošu (u sadri) Vanje Radauša i Frana Kršinića.

Portretnom kiparstvu pripada i A.G. Matoš Emila Bohutinskyja, odliven u bronci i postavljen na dugu horizontalnu podlogu. Oslonjen na lijevu ruku podignutu do čela (desna je ostala nedefinirana, zarobljena u materiji spomenika), Bohutinskyjev Matoš, izdužena, upala lica, djeluje sumorno i zamišljeno, zapravo turobno. Nevelika, vodoravno položena figura (svega $26 \mathrm{~cm}$ visine) napravljena je 1975. godine, a čuva se u Gradskom muzeju u Križevcima.

Od poznatijih skulptura spomenuti je i Matoševo poprsje kiparice Mirjane Drempetić Hanžić-Smolić, izrađeno na prijedlog i u suradnji s Udrugom

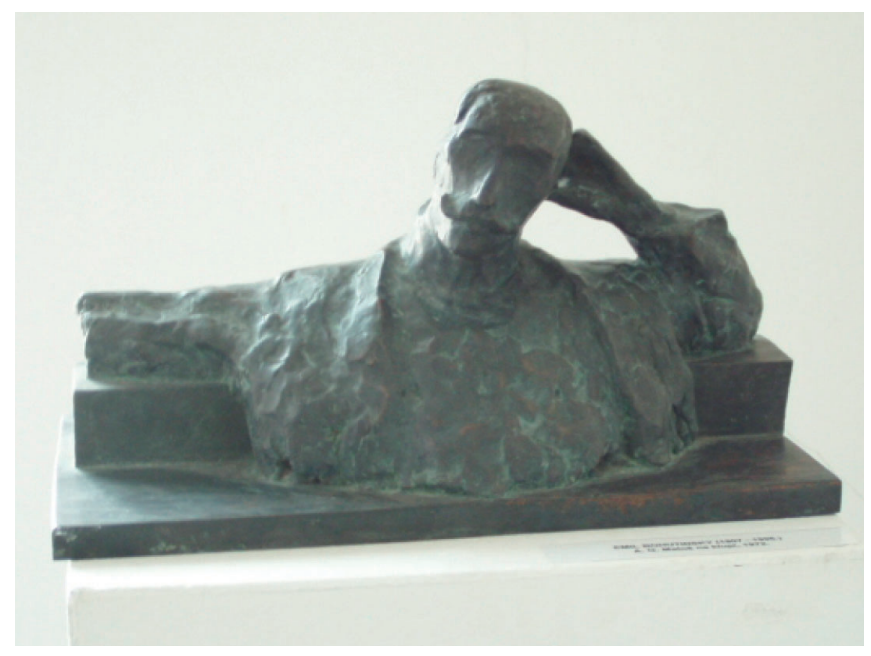

Emil Bohutinsky, Studija A.G. Matoš, Gradski muzej u Križevcima, bronca, 1975. 


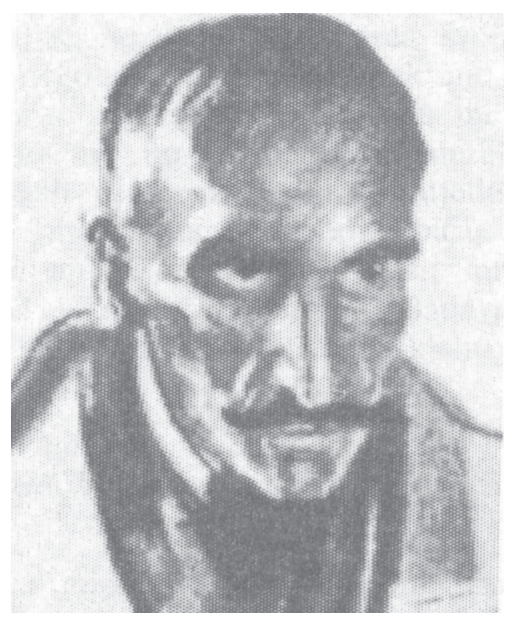

Ljubo Babić, Portret A.G. Matoša, 1913., objavljen u knjizi Umorne priče 1917.

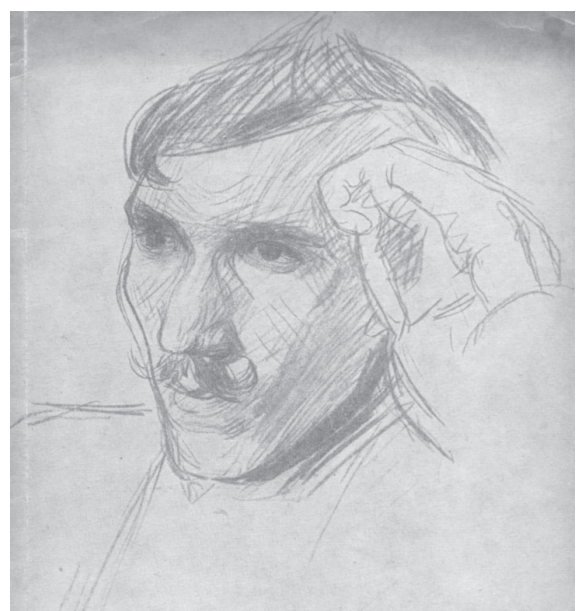

Buisset, Antun Gustav Matoš, crtež olovkom, Pariz 1901.

„Muži zagorskoga srca” i postavljeno 2007. godine pred Gimnazijom Antuna Gustava Matoša u Zaboku.

A kad je o likovnoj Matošu posvećenoj baštini riječ, navodimo i slikarske radove. Dva su od četiriju poznatih i za Matoševa života nastala portreta načinila dvojica njegovih pariških prijatelja, Buisset (crtež olovkom, Pariz 1901.) i Ernest L. Gubelin (nastao 1902., reproduciran 1913. u Matoševoj knjizi Pečalba). Treći je portret izradio hrvatski slikar Ljubo Babić 1913. godine u Zagrebu (objavljen u knjizi Umorne priče. Vidici i putovi, Zagreb 1917.). U povodu 80-e obljetnice Matoševa rođenja objavio je Ljubo Babić zanimljiv članak Kako sam crtao Matoša, gdje se prisjeća kako se pjesnik opirao portretiranju uz smijeh: „Em ja nis spomenik (...), a nis ni tak lep da bi me trebalo molovati" (Babić 1953: 6). Pristao je tek kad mu je obećao da ne mora pozirati, nego neka čita ili piše, i dok je uz duhovite monologe doista pisao, fiksirao je slikar zgrčene prste Matoševe ruke, lubanju istaknuta čela i jakih ličnih kostiju - glavu kao isklesanu - te duboko usađene oči koje se nisu mogle zaboraviti. Najzad je student slikarstva i grafike Ivan Palčić nacrtao Matoša (ugljen, 1913.), i to je posljednji za života nastao portret. Kasnije je samouki slikar Luka Rupčić objavio portret Matoša u knjizi 


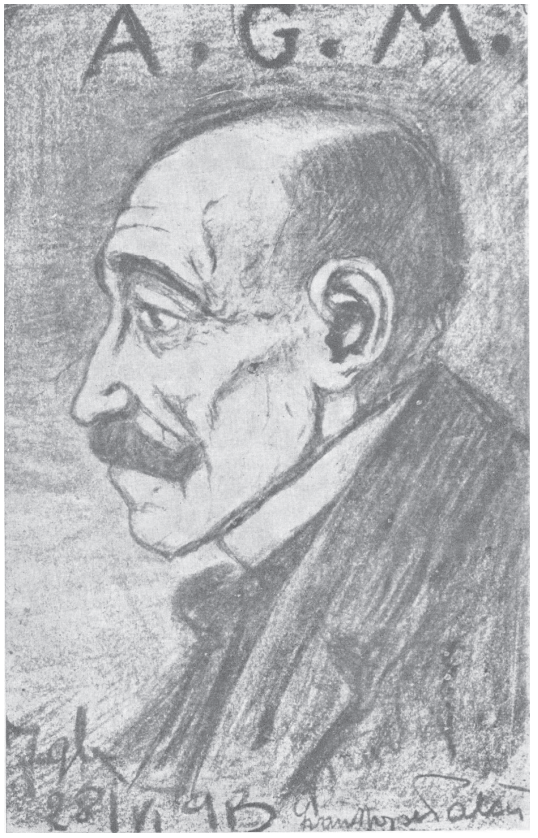

Ivan Palčić, Karikatura A.G. Matoša, crtež ugljenom, 1913.

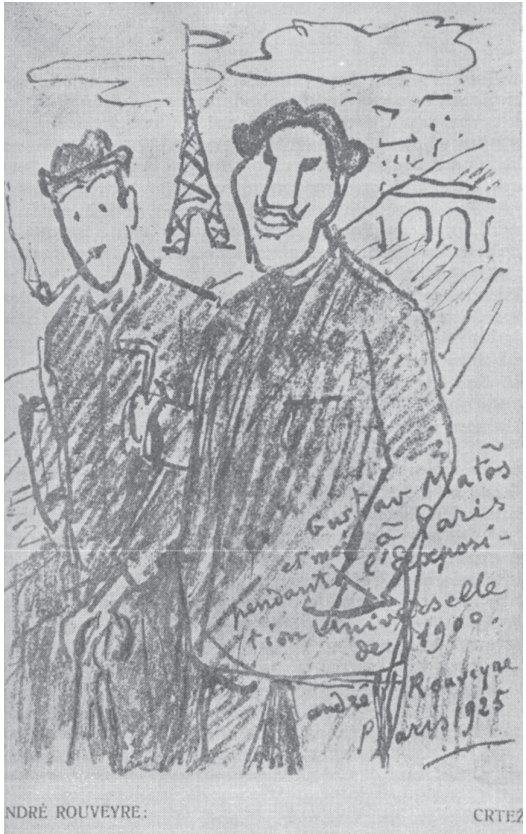

André Rouveyre, Matoš i ja u Parizu za vrijeme Svjetske izložbe 1900., karikatura, 1925.

Dok je srca bit će i Kroacije (Zagreb 1925.), a zacijelo ima i drugih, prema fotografijama i/ili prema narudžbi naslikanih Matoševih portreta, no oni nisu u fokusu zanimanja meritorne struke, pa dakle ni od općega nacionalnog interesa ${ }^{19}$.

Karikature A.G. Matoša dokazom su njegove popularnosti te uz njegovo ime vezanih i umnožavanih kontroverzija. Posebno je zanimljiva povijest karikature Andréa Rouveyrea (crtež, 1925.), na kojoj slikar na francuskom jeziku opisuje njezin sadržaj (u prijevodu: Matoš i ja u šetnji u vrijeme Svjetske izložbe u Parizu 1900.). Nakon četvrt stoljeća, godine 1925., prisjećao se slikar prijatelja Matoša - krupne figure, brkata, sa štapom - te

19 Zahvaljujući svojim bivšim učenicima, i sama posjedujem jedan takav naručeni Matošev portret, rad pok. slikara Stjepana Jozića, bivšega ravnatelja Galerije u Vinkovcima. 


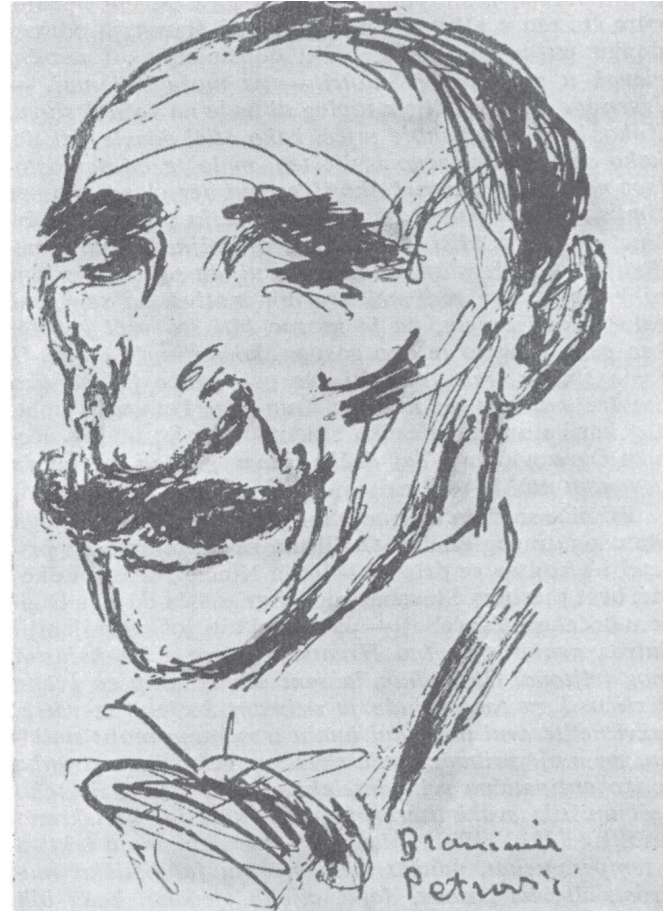

Branimir Petrović, Karikatura A.G. Matoša, 1909.

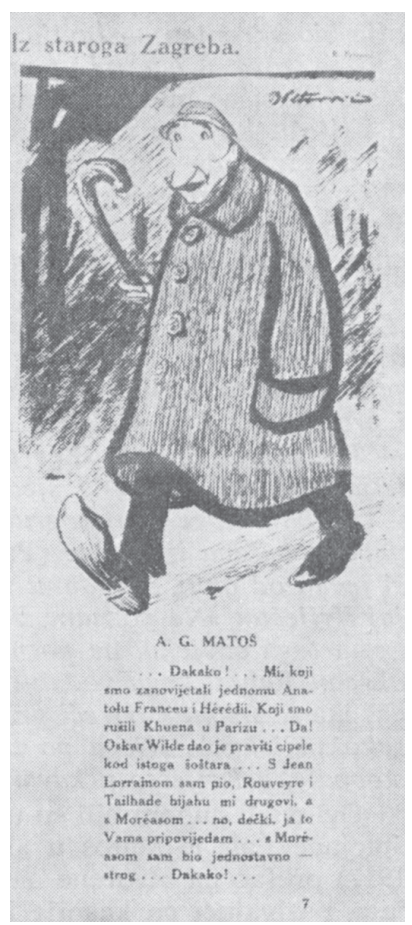

Branimir Petrović, Karikatura A.G. Matoša, 1910.

izradio crtež kao originalnu litografiju. Kamen i prvi litografski otisak poslao je Matoševu bratu Milanu, a danas se čuva u Zavodu za povijest hrvatske književnosti, kazališta i glazbe HAZU u Zagrebu, zajedno s ukupnom Matoševom ostavštinom. Crtež je prvi put objavljen u "Savremeniku” (1926.) kao prilog Rouveyreovu na francuskom jeziku napisanom članku Fragmentarne uspomene na A.G. Matoša.

Poznati hrvatski karikaturist i slikar Branimir Petrović bio je fasciniran Matoševim likom kao zahvalnim motivom. Izradio je tri poznate karikature: prva je načinjena za slikarovih studentskih dana 1909. i objavljena iste godine u „Hrvatskoj smotri”, druga prikazuje Matoša sa štapom (objavljena u humoristično-satiričnom listu „Koprive”, 23.12.1910. - slika 9.), a tekst 


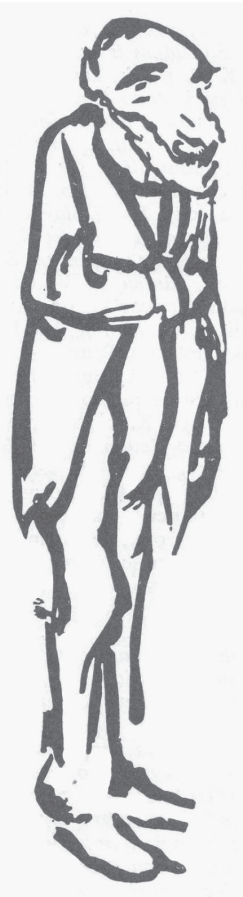

Branimir Petrović, Karikatura A.G. Matoša, 1938.

ispod karikature napisao je, prema vlastitoj izjavi, Krešimir Kovačić duhovito komentirajući Matoševe relacije s uglednim francuskim književnicima. Treća je nastala u Ženevi 1938. na molbu Karla Häuslera (prvi je put objavljena te godine u tjedniku ,7 dana”), a prikazuje Matoša kao žrtvu sredine. Karikaturu je Häusler objavio i u svojoj knjizi memoarskih zapisa Uspomene na A.G. Matoša (1941).

Također je poznat triptih karikatura Pjera Križanića Matoševe plejade I, II, III. (objavljen u „Koprivama” 1911.), a prikazuje Rabija okružena učenicima: Tinom Ujevićem, Krešimirom Kovačićem (koji je napisao i tumač trima karikaturama), Lj. Wiesnerom, Nikolom Polićem, Kostom Hlavatyjem, Ivanom Lorkovićem, Stjepanom Parmačevićem i Karlom Häuslerom. U nešto užemu sastavu (a dodavši sebe): Matoš-Wiesner-Ujević-Kovačić-Križanić-Polić-Häusler, objavio je Križanić karikaturu u svojem članku A.G. Matoš i njegov literarni krug („Politika”, 27.04.1940.).

Osim toga, ondašnji su periodici donosili i anonimne karikature A.G. Matoša, jer je očito njegov nemiran život i radikalan književni angažman izazivao pozornost ilustratora onodobnog tiska. Među tima poznatija je karikatura M. Ogrizovića, Josipa Franka i A.G. Matoša objavljena u splitskom listu „Duje Balavac” (1908.), tri karikature Matoša otisnute u „Koprivama” uz tekst A.G. Matoš - contra Vrbanić (u studenome 1912.), i također u „Koprivama” (30.08.1913.) objavljena karikatura pod naslovom A.G.M. u „Hrvatskoj” koja aludira na njegovu suradnju u pravaškom glasilu „Hrvatska”.

\section{Matoš u Tovarniku}

I dok se središnji hrvatski grad Zagreb baš i nije žurio spomenički obilježiti Matošev život i djelo, malo se srijemsko selo Tovarnik (gdje je 
budući velikan rođen!) od sedamdesetih godina XX. stoljeća svesrdno trudilo oko Matoševa udomljenja u svojoj sredini. Osnovna škola u selu nazvana je njegovim imenom, a ispred škole postavljeno je o 60-oj obljetnici smrti 1974. godine Matoševo poprsje, rad kipara Mihaela Kajfeša. U istom nastojanju postavljena je na rodnoj kući o 125-oj obljetnici rođenja 1998. godine spomen-ploča, rad kipara Mladena Mikulina, s tekstom Dragutina Tadijanovića.

Sve do danas to srijemsko selo na granici sa Srbijom ulaže napore da trajno sačuva uspomenu na svoga najvećega sina, a sada posebice o tomu brine Društvo Antuna Gustava Matoša (1999.), kojemu je glavni cilj izgradnja i uspostava rada Matoševe spomen-kuće na temeljima kuće u kojoj je davne 1873. godine rođen, i gdje bi najzad bio smješten i multimedijski kulturni centar. Izradbu idejne projektne dokumentacije i koncepciju stalnog postava povjerilo je Društvo ekspertnom timu tvrtke Muze, već dokazanome u poslu kreiranja i osmišljavanja kulturnih programa. U vizualiziranu projektu vidjet ćemo tadašnji Tovarnik, upoznati Matoševu obitelj i prijatelje, a na peronu i u vagonima proći s Matošem trnovite postaje prognanika putnika zagrebačko, beogradsko, ženevsko i pariško boravište.

Dovršena nedavno, spomen-kuća inačica je tradicionalne slavonske kuće, projektirana prema izgledu na slici sačuvane prizemnice Matoševa rođenja, s trijemom prema prostranom dvorištu i sa zgradom u dnu, gdje će biti smještena knjižnica i čitaonica, spomenička knjižnica i dokumentacijski centar. Na lijepo pročelje nove kuće prenesena je postojeća Mikulinova brončana spomen-ploča. Godine 2010. osnovana je Zaklada kojoj je svrha promicati, zaštićivati i valorizirati Matoševo književno djelo podignuto na razinu nacionalnoga i europskoga književnog i kulturnog dobra.

\section{Završne riječi}

Kronološki pregled likovne ostavštine potaknute i inspirirane Matoševim likom i djelom, slikarske, kiparske i graditeljske, svjedoči kako je navedeni korpus umjetnina rastao s odmakom od žive Matoševe nazočnosti među Hrvatima, bez obzira na to što enigmu Matoš nije moguće do kraja i zasvagda rasvijetliti - perom opisati, olovkom i tušem nacrtati, kistom naslikati, alatom oblikovati. Nisu to uspjeli autori koji su mu posvećivali 
znanstvene studije, magisterije i disertacije, ni brojni njegovi apologeti, ni učeni književni kritičari i povjesničari, a nisu ni likovni umjetnici. Uvijek je jednim dijelom izmicao, poput svih koji veličinom nadmašuju vrijeme i prostor svojih fizičkih biografija, zračeći sjajem vječnosti. Umjetnik i vizionar u svakom potezu nadarena pera, zagovarao je europsku budućnost Hrvatske i sâm je punom snagom i neiscrpnim stvaralačkim potencijalom živio, upisavši u magiju književne riječi svoj osobni, nacionalni i općeljudski usud.

\section{Literatura}

Anonimno, 1938, Matošev spomenik na pragu Zagreba čeka da uđe u Zagreb, „Večer” br. 5313, 13.08., str. 3 .

Babić Lj., 1953, Kako sam crtao Matoša, „Narodni list” br. 2481, str. 6.

Čorkalo Jemrić K., 2008, Neumrli Matoš, u: Slavonica 3, Vinkovci, str. 11-15.

Denegri J., 2006, Ivan Kožarić, Sisak.

Frangeš I., 1982, Krleža i Matoš, „Forum” br. 10-12, str. 690-740.

Frangeš I., Tadijanović D. (prir.), 1994, Matošiana, knj. 34, Zagreb.

(HDU) Vješanje redarstveno utvrđenih komunista i djelatnih partizana, 1943, „Hrvatski narod" br. 916, str. 10.

Ivakić B. (ur.), 1938, Uspomeni A.G. Matoša, Zagreb.

Krleža M., 1977, Dnevnik 1943, Sarajevo.

Krleža M., 1988, Pjesme A.G. Matoša, u: idem, Svjetiljke u tmini, Sarajevo, str. 199-200.

Lončar M., 2014, Kožarićev Matoš u Parizu, ,Vijenac” br. 520, str. 2.

Matoš A.G., 1939a, Oko Zagreba i po Hrvatskoj, u: idem, Djela, sv. 8, ur. J. Benešić, Zagreb.

Matoš A.G., 1939b, Pečalba, Kaprisi i fejtoni, u: idem, Djela, sv. 9, ur. J. Benešić, Zagreb.

Matoš A.G., 1995, Nedovršena Autobiografija, u: idem, Putopisi, Vinkovci.

Pintar M., 2002, Ivakić, Branimir, u: Hrvatski biografski leksikon, sv. 6, ur. T. Macan, Zagreb, str. 62-63.

Tenžera V., 1978, Klupa - Panteon skitnice, „Vjesnik”, 4. lipnja, str. 8.

Vončina N., 2005, Gršković, Branimir, u: Hrvatski biografski leksikon, sv. 5, ur. T. Macan, Zagreb, str. 244.

Žeželj M., 1970, Tragajući za Matošem, Zagreb. 